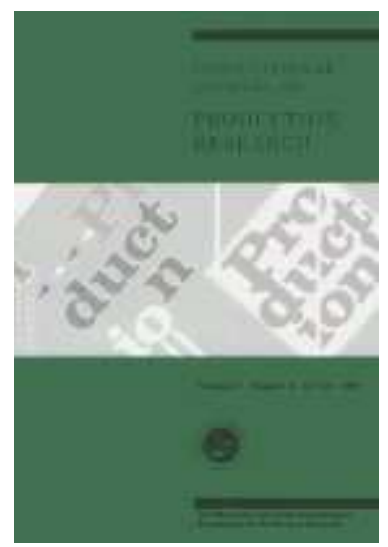

\title{
Strategic Purchasing, Supply Management Practices and Buyer Performance Improvement: An empirical study of UK manufacturing organisations
}

\begin{tabular}{|r|l|}
\hline Journal: & International Journal of Production Research \\
\hline Manuscript ID: & TPRS-2007-IJPR-0132.R2 \\
\hline Manuscript Type: & Original Manuscript \\
\hline Author: & $18-$ Sep-2007 \\
\hline Complete List of Authors: & $\begin{array}{l}\text { Lawson, Benn; Queen's University Belfast, Department of } \\
\text { Management } \\
\text { Cousins, Paul; Manchester Business School, Decision Sciences and } \\
\text { Operations Management } \\
\text { Handfield, Robert; North Carolina State University, Department of } \\
\text { Management } \\
\text { Petersen, Kenneth; Colorado State University, Department of } \\
\text { Management }\end{array}$ \\
\hline Keywords: & SUPPLY CHAIN MANAGEMENT, PURCHASING \\
\hline Keywords (user): & Structural Equation Modelling, Buyer-Supplier Relationships \\
\hline & \\
\hline
\end{tabular}

\section{$\diamond$ ScholaroNE" \\ Manuscript Central}




\title{
Strategic purchasing, supply management practices and buyer performance improvement: An empirical study of UK manufacturing organisations
}

\author{
Benn Lawson* \\ School of Management \& Economics \\ Queen's University Belfast \\ Belfast BT7 1NN \\ United Kingdom \\ Phone: +44 (0) 2890973274 \\ Email: b.lawson@qub.ac.uk \\ Paul D. Cousins \\ Manchester Business School \\ The University of Manchester \\ Manchester M15 6PB \\ United Kingdom \\ Phone: +44 (0) 1612003459 \\ Email: paul.cousins@mbs.ac.uk \\ Robert B. Handfield \\ Department of Business Management \\ College of Management \\ North Carolina State University \\ Raleigh, NC 27695-7229 \\ Phone: (919) 515-4674 \\ Fax: (919) 515-6943 \\ Email: Robert_Handfield@ncsu.edu
}

Kenneth J. Petersen

Department of Management

Colorado State University

Fort Collins, CO 80523-1275

Phone: (970) 4910551

Email: Kenneth.Petersen@business.colostate.edu

* Corresponding author

+ Authors contributed equally. The authors gratefully acknowledge the financial support and access provided by the Chartered Institute of Purchasing and Supply (CIPS), United Kingdom. 


\title{
Strategic purchasing, supply management practices and buyer performance improvement: An empirical study of UK manufacturing organisations
}

\begin{abstract}
Purchasing is increasingly seen as an important strategic activity of the firm. However, there is little evidence examining the effects of strategic purchasing on a firm's inter-organizational supply management practices and performance. The purpose of this paper is to examine the effect of strategic purchasing on the supply management practices of socialization, supplier integration and supplier responsiveness, together with relationship performance. Using empirical data collected from 111 United Kingdom purchasing executives, a structural equation model is used to test the theoretical framework. The results provide support for four of the six hypotheses developed. Strategic purchasing was found to have an indirect, significant effect on improving buyer performance, acting through supplier integration. Strategic purchasing also had a significant effect on the use of socialization mechanisms, but not on supplier responsiveness. Our research indicates that close, long-term supplier relationships can lead to the creation of relational rents. Implications for future research and suggestions for improving the rigour of strategic purchasing research are made.
\end{abstract}

\section{Key Words}

Buyer-supplier relationships, strategic purchasing, supply management, structural equation modeling 


\section{Introduction}

The purchasing function is becoming widely recognised as an important contributor to strategic success, helping firms meet the challenges of an increasingly competitive and dynamic environment (Monczka, Trent and Handfield, 2000). To fulfil this strategic role, the purchasing role within many firms has undergone a marked shift evolving from a tactical service function to a strategic, integrative process (Carr and Pearson, 2002, Carter and Narasimhan, 1996). Strategic purchasing allows the function to play a greater role in corporate planning, reduces a firm's exposure to opportunistic behaviours, and is more likely to lead to successful collaborative relationships (Chen, Paulraj and Lado, 2004). However, realising the gains from strategic purchasing is difficult, with research suggesting that it is a capability requiring years to develop through focused leadership and change management (Handfield and Nichols Jr, 1999).

Early studies on strategic purchasing emphasized the need for an elevated role for purchasing in the development and implementation of corporate strategy (Reck and Long, 1988), while other research has examined the factors underlying the strategic purchasing construct (Carr and Smeltzer, 1997, Carter and Narasimhan, 1996, Narasimhan, Jayaram and Carter, 2001). A number of studies have shed light on the impact of strategic purchasing on the business practice within the firm. Carr and Pearson (1999), for example, examined the effect of strategic purchasing on financial performance, while a later study investigated the antecedents of strategic purchasing and effects on performance (Carr and Pearson, 2002). More recently, Chen et al. (2004) explored the impact of strategic purchasing on supply management capabilities and financial performance. However, a critical mass of empirical work analysing the extent to which purchasing strategy influences purchasing practice has yet to develop (Chen and Paulraj, 2004). 
In this study we explore the effects of strategic purchasing on external parties, specifically the inter-organizational relationships with key suppliers. We argue that it is not enough for a firm to possess a strategic purchasing orientation; they must also create conditions that allow the buyer and supplier to contribute and develop the relationship. Whilst there has been a wide variety of research focusing on inter-firm relationship management, this paper contributes to knowledge by explaining how buyer performance can be enhanced through both process and structural practices. Three supply management practices are identified which facilitate effective relationship performance with key suppliers, namely: socialization activities; process integration; and supply base responsiveness. These variables reinforce one another and act to make the connection between the foundations established by strategic purchasing and the returns derived from a firm's supplier relationships. We add to the literature by specifying a unique set of variables which have not been explicitly modelled in this context, and show that while strategic purchasing can create alignment with long-term business strategy, it must also be deployed into operational processes in order to drive advantage.

We develop a series of hypotheses linking the various constructs, and test them via a mail survey of 111 manufacturing firms located in the United Kingdom. A structural equation model, using AMOS 6.0, is then used to test the predictive power of the model, encompassing all the constructs of interest simultaneously. The research outcomes then derived from this study provide a rich context for future researchers to follow.

The remainder of this paper proceeds as follows. We first provide a review of the extant literature, focusing on strategic purchasing and supply management practices. The conceptual model and rationale for each hypothesised relationship is then developed. Section 3 discusses the research methodology, with the discussion and implications of the study's findings presented 
in Section 4. The paper concludes with a review of the limitations of the study and suggestions for future research.

\section{Literature Review}

\subsection{The resource-based view and strategic purchasing}

The traditional resource-based view (RBV) argues that supernormal earnings result from resources controlled by a single firm (Barney, 1991). However, the rapid growth of collaborative relationships across many industries has expanded this focus, with scholarly attention beginning to recognise the importance of resources which lie outside of a firm's boundaries (Duschek, 2004, Mathews, 2003). Complementary resource combinations between partnering firms can be a source of competitive advantage, with the idiosyncratic nature of the relational assets making imitation by competitors difficult (Gulati, Nohria and Zaheer, 2000). Our study is thus positioned within a framework of collaborative advantage (Dyer and Singh, 1998), rather than one of competitive advantage.

Collaborative advantage is a resource that requires a long-term orientation and may ultimately create greater benefits than a traditional zero-sum based approach to competition (Dyer, 2000). Specifically, we rely on the relational view (Dyer and Singh, 1998), an extension of RBV incorporating social network theory (Burt, 1992, Eisenhardt and Schoonhoven, 1996, Granovetter, 1985). Through cooperation, partners can profit from rents that can only be generated by working jointly. The ability of the firm to derive these relational rents is at least, in part, dependent on how effective the supply function is in building and leveraging collaborative partnerships with suppliers. Dyer and Nobeoka (2000), for example, provide evidence that Toyota's approach to creating and managing a high-performance knowledge-sharing production 
network generates considerable advantage for both the company and its suppliers. Later studies suggest that relational benefits are long-term and sustainable in nature (Choi and Hong, 2002).

\subsection{Strategic purchasing}

Purchasing is increasingly regarded as a strategic weapon, centred on its ability to create collaborative relationships for firm advantage (Carr and Smeltzer, 1999). Numerous authors have highlighted the key concepts of strategic purchasing, including a proactive, long-term focus, and managing supplier relationships strategically (Carr and Smeltzer, 1997, Carter and Narasimhan, 1993, Reck and Long, 1988). Consistent with previous literature, we define strategic purchasing as a planning process that will "direct all purchasing activities toward opportunities consistent with the firm's capabilities to achieve its long-term goals" (Carr and Smeltzer, 1997: 200).

Our study, grounded in the relational view, argues that partnerships with suppliers can have a strong positive influence on firm performance through the development of joint resources and the exchange of valuable knowledge with these individual partners (Dyer, 1996, Dyer and Nobeoka, 2000). In practice, many firms fail to realize these benefits when they implement sourcing agreements at a lower negotiated price, but do not follow through with the relational processes that capture these benefits over the course of the contract (Monczka, Petersen, Handfield and Ragatz, 1998). However, the ability to extract such benefits from supplier relationships is also linked to the way these relationships are managed. For example, those relationships characterised by close interactions and successful process integration between buyer and supplier are better able to create, coordinate and protect joint resources for a sustained competitive advantage (Dyer and Singh, 1998). Thus, it is not enough for a firm to possess a 
strategic purchasing orientation, they must also create conditions which allow the buyer and supplier to contribute and develop the relationship. Various supply management practices facilitate this process, and are discussed below.

\subsection{Supply management practices}

\section{Socialization mechanisms}

The concept of socialization is well established in organizational behaviour research. The early seminal research of Van Maanen (1976) into new employee role socialization led to additional studies applied to other fields including goal and value orientation (Kraimer, 1997), consumer behaviour (Moschis and Churchill, 1978), ethical sensitivity (Sparks and Hunt, 1998), and joint venture agreements (O'Donnell, 2000). Within a supply chain context, socialization has received limited attention (cf. Cousins, Handfield, Lawson and Petersen, 2006). Supply chain socialization refers to the level of interaction and communication between various actors of each firm, leading to personal familiarity, improved communication, and problem solving. Socialization mechanisms, therefore, relate to the processes by which each party acquires knowledge of the other enterprise's social values and norms (Van Maanen and Schein, 1979). The trust, respect and reciprocity built from this engagement increases the willingness of parties to make relationship-specific investments (such as human and intellectual assets), which can be leveraged for advantage in the marketplace (Dyer, 1997).

\section{Supplier integration}

Integration with suppliers has often been cited as an effective strategy for improving business performance (Narasimhan and Das, 2001, Rosenzweig, Roth and Dean Jr, 2003). We focus on 
integration with suppliers at the operational level. Operational integration is intended to make the supplier an extension of the firm's factory, emphasising continuity of supply and an end-toend pipeline (Handfield and Bechtel, 2002). Mechanisms for facilitating this integration include the participation of suppliers in design, procurement, and production, as well using ordering systems and information technology to exchange information (Dyer, 1996). The development of a strategic partnership approach is fundamental to the success of supplier integration efforts (Wagner, MacBeth and Boddy, 2002), with integrating suppliers into a well-managed supply chain having a lasting effect on the competitiveness of the entire supply chain (Choi and Hartley, 1996).

\section{Supplier responsiveness}

Supplier characteristics can have a large impact on the performance of the buyer firm, both in theory (Mathews, 2003) and in practice (Hoetker, 2005). Aligning the supply base to the firm and its environment is a key determinant of supply chain performance (Fisher, 1997), requiring purchasing to take a strategic focus (Chen et al., 2004) and to work on a much more 'integrated' basis with suppliers (Handfield and Bechtel, 2002). We use the idea of supply base responsiveness to reflect the degree to which a firm's key suppliers are able to customize products, be responsive to delivery changes, and to accept late 'mix' and volume changes. Supply chain responsiveness can thus be a source of increased profitability (Towill, Lambrecht, Disney and Dejonckheere, 2003) and competitive advantage (Stalk and Hout, 1990).

\section{Conceptual Model and Hypotheses}


Figure 1 illustrates our conceptual model linking strategic purchasing, supply management practices, and buyer performance improvement. We argue that the strategic orientation set by a proactive purchasing function leads to the development of certain supply practices, namely socialization, integration and responsiveness. In turn, these practices act as the conduits through which the relationship is built, knowledge transferred, and performance improvements for the buyer achieved. Each of the hypothesised relationships is developed below.

\section{[Insert Figure 1 about here]}

\subsection{Linking strategic purchasing and supply management practices}

Strategic purchasing requires a proactive long-term view to supplier relationship management, leading to closer, cooperative links with key suppliers (Chen et al., 2004). One means of forging these links is through bridging mechanisms that transcend the horizontal boundaries between the firms. Socialization mechanisms fulfil this role, acting to structure the engagement, communicate expectations and share useful knowledge between exchange partners. Examples include cross-functional teams, co-location, regularly scheduled meetings and conferences, and matrix style reporting structures. Although we do not specify the exact mix of structures that produce the desired results, cross-functional teams combined with regular supplier team meetings are a "bedrock" for enhanced team interaction (Handfield, Ragatz, Petersen and Monczka, 1999). We argue that as the purchasing function adopts a strategic orientation, the senior management team will increase its use of socialization mechanisms with suppliers as a means of transmitting their cultural values and signalling their commitment to a collaborative, long-term relationship. Thus, 
Hypothesis 1. Strategic purchasing has a positive effect on the level of socialization mechanisms.

A strategic purchasing orientation necessitates a cooperative approach to the management of key suppliers. De Toni and Nassimbeni (1999), for example, found that a long-term relationship perspective increased the intensity of buyer-supplier coordination. Each party must commit relational assets, both human and physical, to developing this relationship and enable closer coordination of activities. Closer integration with suppliers is a means of safeguarding investments specific to the relationship (Heide and Stump, 1995), and increasing the willingness of the supplier to make relationship-specific asset investments (Dyer, 1996). Thus, as a firm adopts a strategic purchasing orientation they will seek to increase the level of operational integration with their key suppliers. Thus,

Hypothesis 2. Strategic purchasing has a positive effect on the level of supplier integration

Strategic purchasing also requires a firm to specify the types of relationships they wish to form with the supply base. In recent years, firms have restructured their supply bases through a process of supplier tiering to reduce the number of suppliers they deal with. First tier suppliers then become the focus of intensive collaboration, where the buyer and supplier align their various organisational systems to enable very close interaction (Stuart, Deckert, McCutheon and Kunst, 1998). This alignment is designed to synergistically enhance skills, share learning, develop new designs and reduce costs by taking out wasteful processes (Womack and Jones, 
1994). We propose that as firms pursue a strategic purchasing orientation, the supply base will be more suited to the buyer, and more responsive to their needs. Thus,

Hypothesis 3. Strategic purchasing has a positive effect on the responsiveness characteristics of a firm's suppliers

\section{2. $\quad$ Linking supply management practices to buyer performance improvement}

We examine the effect of supply chain management practices on buyer performance improvement, specifically on dimensions of product development, process design and product quality. The importance of socialization, supplier integration and supplier responsiveness in driving performance has a high degree of face validity, especially in the case of specific industries. Take, for example, the automotive industry where Japanese automakers, such as Toyota and Honda, have gained large performance advantages over General Motors and Ford. Each of these companies have strategic purchasing models in place, but Toyota and Honda achieve greater benefits, due to the way they have implemented various supply management practices to drive execution with core suppliers.

To unlock the value that exists in the buyer-supplier exchange, firms will need to effectively manage their inter-firm relationships. Socialization mechanisms help align and adapt buyer-activities to changes in the environment. The shared norms and cooperation created via socialization helps increase information exchange, cooperation between the parties and likelihood of shared resource investments. Thus, higher levels of socialization are likely to result in smoother information flows necessary for effective communication of new product designs, suggestions for process improvements, and higher product quality. This is developed in the following hypothesis: 
Hypothesis 4. Socialization mechanisms are positively related with higher levels of buyer performance improvement

While socialization mechanisms focus on the social side of the relationship, the harder structural elements of the process are equally important. Supplier integration reflects cospecialised resources, and may be an important source of inter-organizational rents. Integration with suppliers has been associated with improved business performance across a range of industries and settings (Droge, Jayaram and Vickery, 2004, Narasimhan and Kim, 2002). Specifically, supplier integration results in higher levels of reliability, delivery times, flexibility and customer satisfaction (Rosenzweig et al., 2003), ultimately making the focal company more competitive (Christopher, 1998). Supply chain integration implies greater alignment between the supply chain and the company's strategies. We argue that as levels of supplier integration increases, buyer performance will improve as measured by product design, process design and product quality. Thus,

Hypothesis 5. Supplier integration is positively associated with higher levels of buyer performance improvement

Kraljic (1983) wrote that “...with traditional sourcing patterns crumbling under the pressures of political, economic and technological change, no company whose profitability could be threatened by a sudden scarcity of an important raw material or the loss of a key supplier can safely continue to rely on reactive purchasing policies." Twenty two years later global firms are still facing these same concerns. In order to mitigate these basic sourcing risks firms have focused on developing 'responsiveness' within their supply base. This has been achieved 
through a variety of mechanisms. Lee (2004: 104) argues that firms who are able to extract competitive advantage from their supply base have supply chains that are "...agile, adaptable and aligned". Moreover, Ahmajian and Lincoln (2001) argue that the Japanese keiretsu supply network offer large benefits of flexibility and control. Araujo, Dubois and Gadde $(1999,2003)$ maintain that supplier resources must be aligned with those of the buyer firm in order to attain a competitive advantage, while Bensaou and Anderson (1999) show that specific investments in the supplier relationship led to greater supplier responsiveness, and in turn, improved supplier performance. Flexible suppliers are better able to align with the buyer's supply chain, and provide input into the design of products, processes and quality procedures. Following these previous studies, we argue that firms who possess higher levels of supplier responsiveness are more likely to extract gains from their supplier relationships.

Hypothesis 6. Supplier responsiveness is positively associated with higher levels of buyer performance improvement

\section{Methods}

This study aims to conduct explanatory research examining the unstructured organizational problem of strategic purchasing and its effect on practices and performance. A positivist epistemological stance was adopted, guiding us to the development and testing of hypotheses grounded in theory. Survey methods are typically applied to help achieve these positivist goals (Meredith, Raturi, Kwasi and Kaplan, 1989). Surveys have been used extensively in production and operations management as a method to test theory-driven expectations of the relationships among variables (Malhotra and Grover, 1998). 


\subsection{Sample and procedure}

A sample of 750 United Kingdom manufacturing firms were surveyed from a database held by The Chartered Institute of Purchasing \& Supply (CIPS), UK. An internet-based survey was administered, with each respondent selected based on job function (purchasing manager or equivalent), plant size (at least 100 employees) and industry sector by SIC code. 128 responses were received, of which 17 were deemed unusable due to missing data. The effective response rate was thus 14.8 percent (111/750), comparing favourably to other web-based studies (e.g. Klassen and Jacobs, 2001).

Of the responding firms, 45 percent were general manufacturing, 13.5 percent electronics, 10 percent specialist manufacturing, 9.9 percent automotive, and 10.8 percent were in industries classified 'other', such as chemicals and pharmaceutical. The final 11 percent of firms had no response to industry classification. The response by position held within the firm was Vice President/Director (14 percent), Senior Manager (57 percent), and junior manager (29 percent). By functional area of responsibility, purchasing returned the greatest number of responses (89.9 percent), with the remainder composed of $R \& D$ and manufacturing managers. No significant mean differences were detected between either of these groups. The average experience in the industry was 9.06 years providing support that our informants were also knowledgeable about the issues under investigation.

We conducted pilot testing with four academics and nine industry contacts to assess the scale items' face validity, and to provide feedback on the content, design and usability of the survey website. Some minor content and design changes were made at this stage. A letter introducing the survey was mailed by CIPS to senior purchasing managers in February 2004. The letter explained the purpose of the research, and contained a link to the survey website. 
Efforts were made to enhance the response rate by sending a follow-up email two weeks after the initial mailing, and by offering respondents a composite summary of results (Forza, 2002).

Tests for non-response bias were conducted by comparing early respondents (responses received within the first two weeks) and later respondents (responses received within the third week or later) (Armstrong and Overton, 1977). A $t$-test of difference was conducted on firm size (employees and sales), and mean responses to each variable. No statistically significant differences were identified at $p<.05$. In addition, we gathered data on sales, employees and industry from 22 purchasing executives who had logged onto the survey website, but did not progress to answering the survey. A t-test of difference along these dimensions between these non-responders and responders was conducted, with no statistically significant differences $(p<.05)$ identified

\subsection{Unit of analysis}

The unit of analysis was the dyadic relationship between buyer and a single strategic supplier. We identified purchasing managers as key respondents who possessed knowledge of the organisation's purchasing function and supplier relationships. These respondents were asked to answer the survey with reference to a specific strategic supplier relationship of which they had detailed knowledge. As a further control we asked whether they had primary responsibility for the management of that relationship, giving us confidence that the respondents were knowledgeable regarding the items under investigation. 


\subsection{Operationalization of variables}

The following measures consisted of items ranging from 1, "not at all", to 7, "a very great extent". All items are reported in Appendix A. Strategic purchasing was measured using a three item scale validated by Carr and Pearson (1999), and developed by Carter and Narasimhan (1993) and Hendrick and Ellram (1993). The items assessed a firm's approach to purchasing strategy through the existence of a formal long range plan, the review of the strategic plan to match changes in corporate strategy, and the inclusion of various types of relationships to be established with suppliers. Although alternative items have been proposed (e.g. Chen et al., 2004), we believe that the scale used in this study continues to offer the most effective and parsimonious measure of assessing the strategic impact of purchasing on firm-level strategy making.

Supply management practices included socialization processes, supplier integration and supply base responsiveness. Socialization mechanisms were assessed using a three-item scale examining the structures and process in place to facilitate socialization activities between the buyer and supplier, such as cross-functional teams, joint workshops, and co-location (Cousins et al., 2006, O'Donnell, 2000). Supplier responsiveness was measured using a four-item scale assessing the responsiveness of a firm's suppliers, including their ability to undertake customisation, and responsiveness to schedule and volume changes. We measured supplier integration using a four-item scale validated by Narasimhan and Kim (2002) and others (Carr and Pearson, 1999, Monczka and Morgan, 1996). The items included the degree of strategic partnership with suppliers, level of supplier participation in design, procurement and production, and the establishment of quick ordering systems. 
Our performance outcome variable, buyer performance improvement was measured using a three-item scale adapted from Kotabe, Martin and Domoto (2003) assessing the degree to which the relationship had, over the past two to three years, resulted in improved product design, process design and product quality for the buyer firm.

\section{Statistical Analysis}

\subsection{Confirmatory Factor Analysis}

A two-step process of analysis (Anderson and Gerbing, 1988), with AMOS 6.0 (Arbuckle, 2005), was employed to test our hypotheses. First, confirmatory factor analysis (CFA) was employed to provide a test of construct validity and unidimensionality using latent and manifest variables. Model identification was achieved by fixing one of the loadings in each construct to a value of 1.0, and having a minimum of three-indicators for each variable. Each indicator within the measurement model then checked for low factor loadings $(<.40)$, high residuals (i.e., normalized residuals $>2.58$ ), and modification indices $(>3.84)$. No anomalies were identified. A check for negative variance and high item correlations revealed no further areas of concern. Table 1 provides the loadings and error terms of the manifest variables onto each latent variable.

\section{[Insert Table 1 about here]}

We assessed model fit using four indices: the chi-square test; the comparative fit index (CFI); the Tucker-Lewis Index (TLI); and the root-mean-square error of approximation index (RMSEA) (Gerbing and Anderson, 1992, Hu and Bentler, 1999). The fit of the CFA to the data was good: $\left[\chi^{2}(109)=120.92, p=.205 ; \mathrm{CFI}=.988 ; \mathrm{TLI}=.986\right.$; and RMSEA $\left.=.032\right]$. A number 
of procedures were then followed to check for convergent validity (Bagozzi and Yi, 1988) and discriminant validity (Anderson and Gerbing, 1988, Fornell and Larcker, 1981). The convergent validity of the scales (extent to which the measurement items reflect a common underlying construct) was supported, with estimated coefficients of all indicators being significant $(t>2.0)$. The average variance extracted (AVE), which measures the variance captured by the indicators relative to measurement error, was also greater than the 0.50 minimum necessary to justify the use of a construct (Hair et al., 1998). Composite reliability values also provide a further assessment of internal consistency. A minimum value of 0.70 is recommended as it indicates that around 0.50 of the variance (the squared loading) can be attributed to the construct of interest (Fornell and Larcker, 1981). The composite reliabilities, which ranged from .78 to .91, were excellent.

All tests of discriminant validity were supportive. That is, no confidence intervals of the correlations for the constructs ( $\phi$ values) included $1.0(p<.05)$ (Anderson and Gerbing, 1988), and the square of the intercorrelations between two constructs, $\phi^{2}$, was less than the AVE estimates of the two constructs. This was true for all pairs of constructs (Fornell and Larcker, 1981). These results suggest the five scales and their 17 items are reliable and valid in this study. The inter-item correlations, Cronbach's alpha, composite reliabilities (CR), and average variance extracted (AVE) values are shown in Table 2. We now proceed to test the structural model.

\section{[Insert Table 2 about here]}




\section{2. $\quad$ Structural model}

The structural model was tested, with maximum likelihood estimation, and the covariance matrix used as input to the model. No over-identifying paths were identified. The fit indices for the structural model indicate an acceptable fit to the data: $\left[\chi^{2}(113)=138.76, p=.05\right.$; $\mathrm{CFI}=.975 ; \mathrm{TLI}=.970 ;$ and RMSEA $=.046]$. The structural model explained 37 percent of the variation in buyer performance improvement. The results are presented in Figure 2, and show that four out of the six proposed hypotheses were supported.

\section{[Insert Figure 2 about here]}

The results show that the majority of constructs are related in the theoretically predicted manner. There was a statistically significant association linking strategic purchasing to socialization mechanisms $(\beta=0.40, p<0.001)$ and supplier integration $(\beta=0.48, p<0.001)$, providing support for $\mathrm{H} 1$ and $\mathrm{H} 2$, respectively. No support was found for $\mathrm{H} 3$, linking strategic purchasing and supplier responsiveness $(\beta=0.14, \mathrm{~ns})$. Supply management capabilities also have positive and significant associations with performance. The hypothesized relationship between socialization mechanisms and buyer performance improvement $(\beta=0.13$, ns) was nonsignificant, thus H4 was not supported. Significant relationships were, however, found linking supplier integration to buyer performance improvement $(\beta=0.49, p<0.001)$ and supplier responsiveness to buyer performance improvement $(\beta=0.29, p<0.001)$, supporting H5 and H6, respectively. Strategic purchasing has a significant total indirect effect on performance $(\beta=0.33$, $p<0.001)$, operating through supplier integration $(\beta=0.23, p<0.01)$. 
In addition, we added a direct path from strategic purchasing to buyer performance improvement as a formal test of mediation. The difference in $\chi^{2}$-values between the baseline hypothesized model and the mediated model $\left(\Delta \chi^{2}(1)=.29\right.$, ns $)$, with one degree of freedom, is a test of the significance of the added path. As this difference is not significant, we may conclude that the direct path from strategic purchasing to buyer performance improvement is insignificant, and therefore strategic purchasing acts through supply management practices to achieve improvements in performance.

\section{Discussion}

The purpose of this study was to examine the role of strategic purchasing on supply chain management practices and performance. We investigated this question in the context of medium-to-large United Kingdom manufacturing firms. Our results provide empirical support that strategic purchasing is significantly and positively related to higher levels of socialization and supplier process integration, as well as having a significant, indirect effect on buyer performance improvements.

A number of contributions are highlighted. First, this study represents an empirical test of the relational view. Our performance variable, buyer performance improvement, measured the returns directly attributable to the relationship between buyer and key supplier. We showed that a strategic purchasing orientation generated relational rents for the firm. Close relationships with suppliers, where trust and cooperation is paramount, rather than competition and opportunism, is thus recommended as an avenue for value creation.

Second, we provide a more detailed investigation of the way in which strategic purchasing impacts on supplier relationships, including boundary-spanning socialization 
activities and integration of operational processes with suppliers. Interestingly, strategic purchasing did not have a significant effect on the responsiveness of a firm's supply base. We partially answer the call of Chen et al. (2004) in broadening the examination of strategic purchasing to other relationship variables. However, more work is still required to examine the impact of strategic purchasing on supplier management.

\subsection{Impact of strategic purchasing on supply management practices}

Our study had proposed three hypotheses relating strategic purchasing to supply management practices. Two of the three relationships were significant and in expected directions. Strategic purchasing led to a significantly increased use of socialization mechanisms with suppliers. Close communication and cooperation with key suppliers is a necessary outcome of strategic purchasing, with socialization mechanisms being an important boundary-spanning process facilitating this goal. Socialization mechanisms are beginning to receive increased attention within the general management literature (Inkpen and Tsang, 2005, Oh, Chung and Labianca, 2004), and also specifically within the supply chain management literature (Cousins et al., 2006, Linderman, Schroeder, Zaheer, Liedtke and Choo, 2004). The results show that socialization mechanisms are an outcome of greater strategic purchasing and can have a significant role to play in the development of supplier relationships, particularly in building informal norms and information flows.

Strategic purchasing was also highly associated with increased supplier integration. Strategic purchasing promotes closer ties with suppliers, and encouraging relationship-specific investments, such as ordering systems, sharing information through IT, and involving suppliers in procurement and production. Purchasing being seen as strategic (important) to the 
organisation also gives it extra bargaining power within the organisation itself. This can have knock-on effects improving internal problem solving, being able to lead selection teams and being viewed as a value generator. For example, a semiconductor firm we interviewed decided to outsource its production to a contract manufacturer in China. The initial process of strategic purchasing and supplier selection was simple. However, once production began, quality problems became rampant, until the firm formally committed to establishing on-site operational personnel to resolve these issues. Integration of processes thus played a critical role in cementing the benefits associated with the outsourcing decision.

Interestingly, strategic purchasing was not significantly related to improvements in supplier responsiveness. It may be that some firms did not require a more responsive supply chain, as would be typical in fast-moving consumer products (Fisher, 1997). Instead, an efficient supply chain focused on cost management may have been more appropriate. This may have contributed to the non-significant findings. It is also very possible that global sourcing issues may interact with these variables, due to the complexity associated with cultural differences, communication difficulties, and time zone differences (Handfield, 1993). A further explanation may be the presence of a time-lag inherent in the interaction of these variables. A strategic purchasing orientation may take a number of years to enact substantial improvements in aligning supplier capabilities (responsiveness) with the needs of the buyer firm. Longitudinal studies may help to shed light on this issue.

\subsection{Impact of supply management practices on buyer performance improvement}

Two of the three hypothesized relationships were significant and in expected directions. Supply management practices of integration and supply base responsiveness led to improved buyer 
performance, while socialization had no significant impact on performance. Supplier integration had the largest impact on relationship performance. The results indicate that firms who build joint investments with suppliers are able to derive greater benefits from the relationship. Such joint investment increases the level dependency between buyer and supplier, facilitating the alignment of organisational systems, sharing of knowledge and learning and improved problem solving. These benefits may manifest themselves in reduced time-to-market, improved design cycles, reduced costs and risk sharing agreements.

In addition, as the supply base becomes more responsive (i.e. ability to change delivery, volume, mix and customisation), greater performance improvements are gained. This is likely due to the greater ability of the supplier to meet buyer firm's needs, efficiently and effectively. Our results do not, however, provide a good explanation for how the responsive nature of the supply base is developed. One method for improving responsiveness is through supplier development. Further research could examine the links between supply base characteristics, strategic purchasing and supplier development. Sako (2004), for example, in her investigation of the automotive industry found that firms were reformulating their governance structures to extend their firm boundaries with suppliers to make joint investment decisions, share intellectual property and co-design development.

Finally, socialization mechanisms were not significantly associated with buyer performance improvement. This is surprising given the strength of research indicating that building knowledge-sharing routines (i.e. through socialization mechanisms) are likely to be key drivers of relational rents (Dyer and Singh, 1998). It may be that although socialization does not have a direct effect, it is possible that it acts to improve the efficacy of other supply management practices, such as process integration and as a conduit to facilitate supplier responsiveness. 
Given these significant results, investment in developing a firm's supplier management capabilities would appear to be a managerial priority. Our research shows that if firms are to become more responsive to their market places they need to build a strategic competence in their purchasing functions. Strategic purchasing leads to improved supplier integration and socialization mechanisms, giving overall improvements in buyer performance. Having a supply chain that can react quickly, efficiently and effectively to intense market pressures would appear to be key to maintaining a sustainable competitive advantage.

\section{Limitations and Conclusions}

No research is without its limitations, and there are some cautions in interpreting the results of our study. First, this study was based on a sample of companies in the CIPS database. Although a wide range of sectors were evident, the results may not be generalisable to all companies. Replication across other industries, including services, as well as international contexts would also increase our understanding of the pervasiveness of strategic purchasing. Informant bias can be an issue in self-reporting surveys (Kumar, Stern and Anderson, 1993). We attempted to minimise the presence of any such bias through the selection of respondents with comparable roles, focusing on organisational and sub-unit performance and avoiding questions of personal performance, as well as by assuring total anonymity and confidentiality such that individual responses could not be identified. In addition, the cross-sectional nature of our data means we are not able to test causal inferences regarding the relationships between strategic purchasing, supply practices and performance. Longitudinal data is required in order to assert causation. Future research based on case studies could provide rich data and would be particularly valuable in substantiating the evolving nature of strategic purchasing functions. 
Our unit of analysis was also restricted to one-side of a dyadic tie between buyer and supplier. Further research could examine the other side of the dyad, namely the supplier. The use of other research methods, such as case studies, could also further expand the focus, shedding light on the entire strategic supply network (Gulati et al., 2000). This study has examined relationships between supply management practices and buyer performance. Future research could investigate their impact on financial performance, or the interactions with other internal functions. What other variables influence strategic purchasing and relationship performance? Relationships between the supply management capabilities examined may also exist, such as between socialization and supplier integration. These relationships were beyond the scope of this study, but would be worthwhile of further investigation.

Although some research is starting to examine the factors influencing strategic purchasing, few have focused on the impact on supply management practices and relationship performance. The analysis presented in this study shows that strategic purchasing has a positive impact on supply management practices and the returns from the supplier relationship. The research indicates that firms can gain a collaborative advantage and extract relational rents from building a distinctive capability in strategic purchasing. The results suggest that significant value can be created "after the ink on the contract has dried" through improved supplier relationship management. 


\section{References}

Ahmadjian, C. L. and LinCOLN, J. R., 2001, Keiretsu, governance, and learning: Case studies in change from the Japanese automotive industry. Organization Science, 12(6), 683-701.

Anderson, J. C. and Gerbing, D. W., 1988, Structural equation modeling in practice: A review and recommended two-step approach. Psychological Bulletin, 103, 411-23.

Araujo, L., Dubois, A., and GadDE, L. E., 1999, Managing interfaces with suppliers. Industrial Marketing Management, 28(5), 497-506.

Araujo, L., Dubois, A., and GADDE, L. E., 2003, The multiple boundaries of the firm. Journal of Management Studies, 40(5), 1255-77.

Arbuckle, J. L., 2005, Amos ${ }^{\mathrm{TM}} 6.0$ User's Guide. United States of America.: Amos Development Corporation.

Armstrong, S. J. and Overton, T. S., 1977, Estimating non-response bias in mail surveys. Journal of Marketing Research, 14(August), 396-402.

BAGOzZI, R. P. and YI, Y., 1988, On the evaluation of structural models. Journal of the Academy of Marketing Science, 16(1), 74-94.

BARNEY, J., 1991, Firm resources and sustained competitive advantage. Journal of Management, 17(1), 99-120.

BensaOU, M. and Anderson, E., 1999, Buyer-supplier relations in industrial markets: when do buyers risk making idiosyncratic investments? Organization Science, 10(4), 460-81.

BuRT, R. S., 1992, Structural holes: The social structure of competition. Cambridge, MA: Harvard University Press.

CARr, A. S. and SMElTzer, L., 1997, An empirically based operational definition of strategic purchasing. European Journal of Purchasing \& Supply Management, 3(4), 199-207.

CARR, A. S. and SMELTZER, L. R., 1999, The relationship of strategic purchasing to supply chain management. European Journal of Purchasing and Supply Management, 5(1), 43-51.

CARr, A. S. and PeArson, J. N., 1999, Strategically managed buyer-supplier relationships and performance outcomes. Journal of Operations Management, 17(5), 497-519.

CARr, A. S. and PEARson, J. N., 2002, The impact of purchasing and supplier involvement on strategic purchasing and its impact on firm's performance. International Journal of Operations \& Production Management, 22(9), 1032-53.

CARter, J. and NArasimhan, R., 1993, Purchasing and materials management's role in Total Quality Management and customer satisfaction. Tempe, AZ.: Center for Advanced Purchasing Studies/NAPM.

CARTER, J. R. and NARASIMHAN, R., 1996, Is purchasing really strategic? International Journal of Purchasing and Materials Management, 32(1), 20-28.

Chen, I. J., PAUlRAJ, A., and LAdO, A. A., 2004, Strategic purchasing, supply management, and firm performance. Journal of Operations Management, 22(5), 505-23.

Chen, I. J. and PAUlRAJ, A., 2004, Understanding supply chain management: critical research and a theoretical framework. International Journal of Production Research, 42, 131.

CHOI, T. Y. and HARTLEY, J. L., 1996, An exploration of supplier selection practices across the supply chain. Journal of Operations Management, 14(4), 333-43.

CHOI, T. Y. and Hong, Y., 2002, Unveiling the structure of supply networks: case studies of Honda, Acura, and DaimlerChrysler. Journal of Operations Management, 20(5), 469-93.

Christopher, M., 1998, Logistics and supply chain management. 2nd ed. London: Financial Times - Pitman Publishing. 
Cousins, P. D., Handfield, R. B., Lawson, B., and Petersen, K. J., 2006, Creating supply chain relational capital: The impact of formal and informal socialization processes. Journal of Operations Management, 24(6), 851-63.

De Toni, A. and NAssimBeni, G., 1999, Buyer-supplier operational practices, sourcing policies and plant performance: result of an empirical research. International Journal of Production Research, 37(3), 597-619.

Droge, C., JayAram, J., and VicKery, S. K., 2004, The effects of internal versus external integration practices on time-based performance and overall firm performance. Journal of Operations Management, 22(6), 557-73.

DusCHEK, S., 2004, Inter-firm resources and sustained competitive advantage. Management Revue, 15(1), 53-73.

DYER, J. H., 1996, Specialized supplier networks as a source of competitive advantage: evidence from the auto industry. Strategic Management Journal, 17(4), 271-91.

DYER, J. H., 1997, Effective interfirm collaboration: How firms minimize transaction costs and maximise transaction value. Strategic Management Journal, 18(7), 535-56.

DYER, J. H. and SINGH, H., 1998, The relational view: cooperative strategy and sources of interorganizational competitive advantage. Academy of Management Review, 23(4), 66079.

DYER, J. H., 2000, Collaborative advantage: winning through extended enterprise supplier networks. New York: Oxford University Press.

DYer, J. H. and NoBEOKA, K., 2000, Creating and managing a high-performance knowledgesharing network: The Toyota case. Strategic Management Journal, 21(3), 345-67.

EISENHARdT, K. M. and SchoOnhoven, C. B., 1996, Resource-based view of strategic alliance formation: strategic and social effects in entrepreneurial firms. Organization Science, 7(2), 136-50.

FISHER, M., 1997, What is the right supply chain for your product? Harvard Business Review, March-April, 105-16.

FORNELL, C. and LARCKER, D. F., 1981, Evaluating structural equation models with unobservable variables and measurement error. Journal of Marketing Research, 18(1), 39-50.

ForZA, C., 2002, Survey research in operations management: a process-based perspective. International Journal of Operations \& Production Management, 22(2), 152-94.

Gerbing, D. W. and Anderson, J. C., 1992, Monte Carlo evaluations of goodness of fit indices for structural equation models. Sociological Methods and Research, 21(2), 132-60.

GranOVETTER, M. S., 1985, Economic action and social structure: The problem of embeddedness. American Journal of Sociology, 9(3), 481-510.

Gulati, R., Nohria, N., and ZaheER, A., 2000, Strategic networks. Strategic Management Journal, 21(3), 203-15.

HANDFIELD, R. B., 1993, Distinguishing attributes of JIT systems in the Make-toOrder/Assemble-to-Order environment. Decision Sciences Journal, 24(3), 581-602.

Handfield, R. B., Ragatz, G. L., Petersen, K. J., and MonczKa, R. M., 1999, Involving suppliers in new product development. California Management Review, 42(1), 59-82.

HANDFIELD, R. B. and BECHTEl, C., 2002, The role of trust and relationship structure in improving supply chain responsiveness. Industrial Marketing Management, 31(4), 36782. 
HANDFIElD, R. R. and NiChOls JR, E. L., 1999, Introduction to supply chain management. Upper Saddle River, NJ: Prentice-Hall.

HeIDE, J. and STUMP, R. L., 1995, Performance implications of buyer-supplier relationships in industrial-markets: A transaction cost explanation. Journal of Business Research, 32(1), 57-.

Hendrick, T. E. and Ellram, L. M., 1993, Strategic Supplier Partnering: An International Study. Tempe, AZ.: Center for Advanced Purchasing Studies/NAPM.

HoETKER, G., 2005, How much you know versus how well I know you: Selecting a supplier for a technically innovative component. Strategic Management Journal, 26(1), 75-96.

Hu, L.-T. and BENTLER, P. M., 1999, Cutoff criteria for fit indexes in covariance structure analysis: Conventional criteria versus new alternatives. Structural Equation Modeling, 6(1), 1-55.

InKPEN, A. C. and TsAnG, E. W. K., 2005, Social capital, networks and knowledge transfer. Academy of Management Review, 30(1), 146-65.

KLASSEN, R. D. and JACOBS, J., 2001, Experimental comparison of Web, electronic and mail survey technologies in operations management. Journal of Operations Management, 19(6), 713-28.

Kotabe, M., Martin, X., and Domoto, H., 2003, Gaining from vertical partnerships: knowledge transfer, relationship duration, and supplier performance improvement in the U.S. and Japanese automotive industries. Strategic Management Journal, 24(4), 293-316.

KraIMER, M. L., 1997, Organizational goals and values: A socialization model. Human Resource Management Review, 7(4), 425-47.

Kraljic, P., 1983, Purchasing must become supply management. Harvard Business Review, (September), 110-17.

Kumar, N., Stern, L. W., and Anderson, J. C., 1993, Conducting interorganizational research using key informants. Academy of Management Journal, 36(6), 1633-51.

LEE, H., 2004, The triple-A supply chain. Harvard Business Review, 82(10), 102-12.

Linderman, K., Schroeder, R. G., ZAHEER, S., LiedTKe, C., and CHOO, A. S., 2004, Integrating quality management practices with knowledge creation processes. Journal of Operations Management, 22(6), 589-607.

Malhotra, M. K. and Grover, V., 1998, An assessment of survey research in POM: from constructs to theory. Journal of Operations Management, 16, 407-25.

MAthews, J. A., 2003, Competitive dynamics and economic learning: An extended resourcebased view. Industrial and Corporate Change, 12(1), 115-45.

Meredith, J. R., Raturi, A., Kwasi, A.-G., and Kaplan, B., 1989, Alternative research paradigms in operations. Journal of Operations Management, 8(4), 297-326.

MonczKA, R. M. and Morgan, J. P., 1996, Supply base strategies to maximize supplier performance. International Journal of Physical Distribution and Logistics Management, 23(4), 42-54.

MonczKa, R. M., Petersen, K. J., Handfield, R. B., and RAGatz, G. L., 1998, Success factors in strategic supplier alliances: The buying company perspective. Decision Sciences, 29(3), 553-77.

MonczKa, R. M., Trent, R. J., and Handfield, R. B., 2000, Purchasing and supply chain management. Cincinnati: South-Western.

Moschis, G. P. and Churchill, G. A., 1978, Consumer socialization: A theoretical and empirical analysis. Journal of Marketing Research, 15(November), 599-609. 
NARAsimhan, R., JAYARAM, J., and CARTER, J. R., 2001, An empirical examination of the underlying dimensions of purchasing competence. Production and Operations Management, 10(1).

NARASIMHAN, R. and DAS, A., 2001, The impact of purchasing integration and practices on manufacturing performance. Journal of Operations Management, 19(5), 593-609.

NARASIMHAN, R. and KIM, S. W., 2002, Effect of supply chain integration on the relationship between diversification and performance: evidence from Japanese and Korean firms. Journal of Operations Management, 20(3), 303-23.

O'DonNell, S. W., 2000, Managing foreign subsidiaries: agents of headquarters, or an independent network? Strategic Management Journal, 21, 525-48.

OH, H., Chung, M.-H., and LABIANCA, G., 2004, Group social capital and group effectiveness: The role of informal socializing ties. Academy of Management Journal, 47(6), 860-96.

RECK, R. F. and Long, B. G., 1988, Purchasing: a competitive weapon. Journal of Purchasing and Materials Management, 24(3), 2-8.

Rosenzweig, E. D., Roth, A. V., and Dean JR, J. W., 2003, The influence of an integration strategy on competitive capabilities and business performance: An exploratory study of consumer products manufacturers. Journal of Operations Management, 21(4), 437-56.

SAKO, M., 2004, Supplier development at Honda, Nissan and Toyota: comparative case studies of organizational capability enhancement. Industrial and Corporate Change, 13(2), 281308.

SPARKS, J. R. and HUNT, S. D., 1998, Marketing researcher ethical sensitivity: conceptualization, measurement and exploratory investigation. Journal of Marketing, 62(2), 92-109.

StalK, G. and Hout, T., 1990, Competing against time: how time-based competition is reshaping global markets. New York: Free Press.

Stuart, F. I., Deckert, P., McCutheon, D., and Kunst, R., 1998, A leveraged learning network. Sloan Management Review, 39(4), 81-94.

Towill, D. R., LAMBrecht, M. R., Disney, S. M., and DejoncKheERE, J., 2003, Explicit filters and supply chain design. Journal of Purchasing \& Supply Management, 9(2), 73-82.

VAn MAAneN, J., 1976, Breaking in: Socialization to work, in Dubin, R. (ed.), Handbook of work, organization and society. Chicago: Rand McNally, 67-130.

VAN MAANEN, J. and ScheIN, E. H. (eds.), Toward a theory of organizational socialization, ed. Staw, B., M. 3 vols. (Research in Organizational Behaviour: An Annual Series of Analytical Essays and Critical Reviews, 1; Greenwich, Connecticut: JAI Press Inc, 1979) 209-64.

Wagner, B. A., MacBeth, D. K., and Boddy, D., 2002, Improving supply chain relations: An empirical case study. Supply Chain Management: An International Journal, 4(7), 253-64.

Womack, J. P. and JoneS, D. T., 1994, From lean production to the lean enterprise. Harvard Business Review, (March - April), 93-103. 


\section{Figure 1 - Conceptual model}

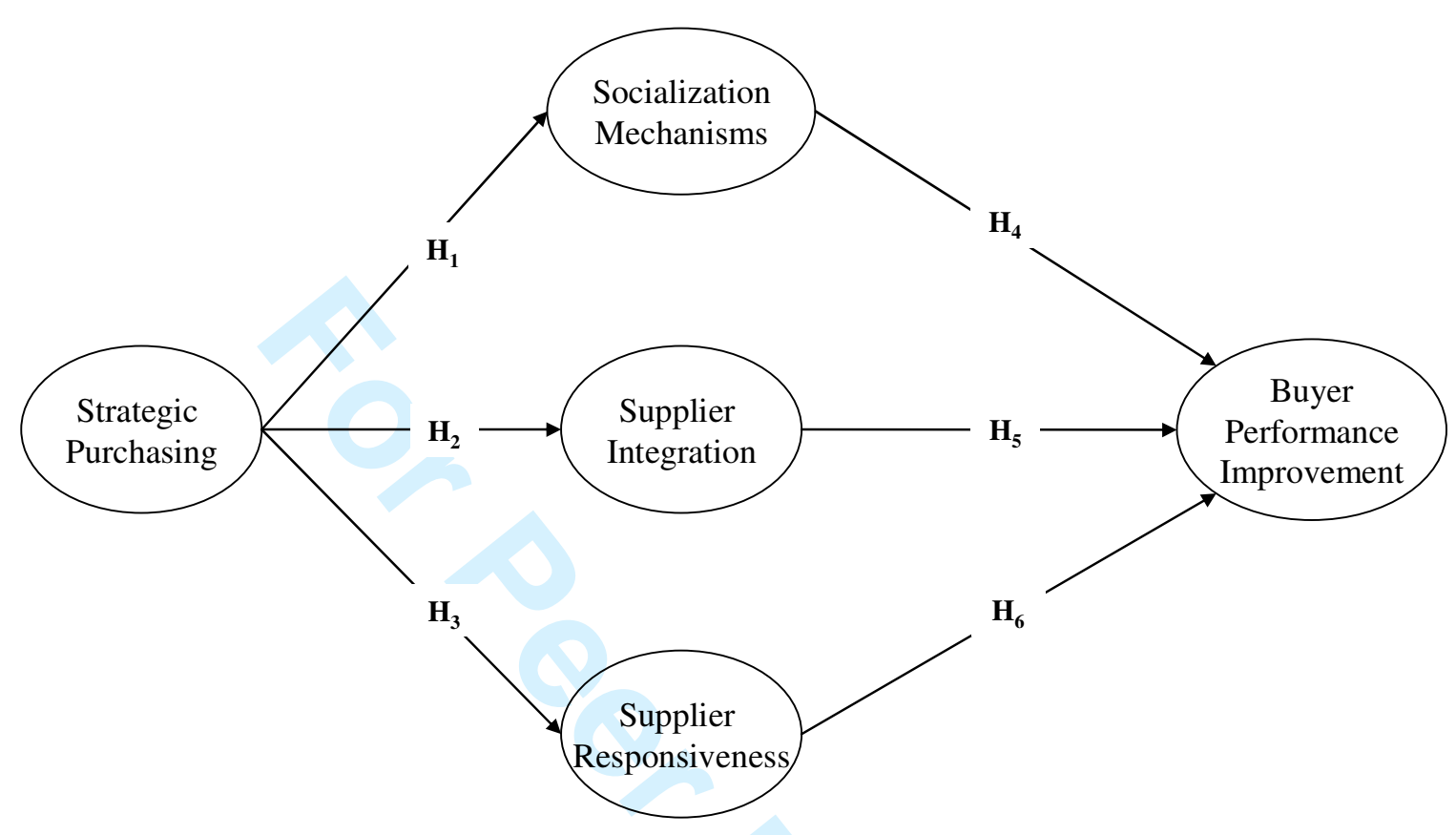

29

30

31

32

33

34

35

36

37

38

39

40

41

42

43

44

45

46

47

48

49

50

51

52

53

54

55

56

57

58

59

60 
Figure 2 - Parameter estimates for the structural model

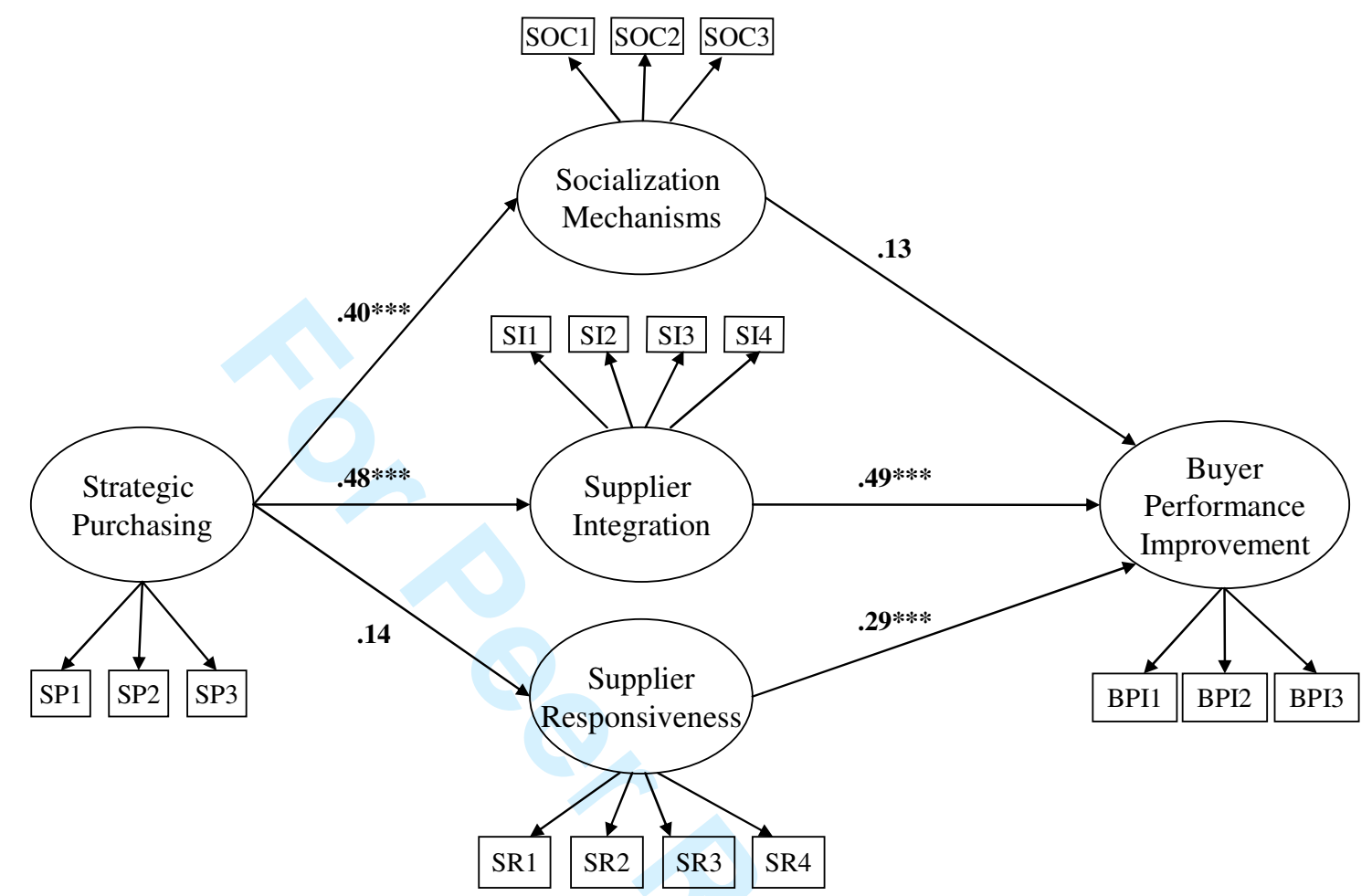

$* p<.05, * * p<.01, * * * p<.001$, all one-tailed tests Error terms and loadings are omitted for clarity 
Table 1 - Assessment of reliability and construct validity

\begin{tabular}{lccc}
\hline \multicolumn{1}{c}{ Factors and Items } & $\begin{array}{c}\text { Estimated } \\
\text { loading }\end{array}$ & $\begin{array}{c}\text { Standardized } \\
\text { loading }\end{array}$ & t-value \\
\hline Strategic Purchasing & 1.00 & .82 & - \\
SP1 & 1.16 & .89 & 10.21 \\
SP2 & 1.11 & .83 & 9.70 \\
SP3 & & & \\
Socialization Mechanisms & 1.00 & .73 & - \\
SOC1 & 1.15 & .81 & 6.59 \\
SOC2 & 1.00 & .69 & 6.20 \\
SOC3 & & & \\
Supplier Integration & 1.00 & .78 & - \\
SI1 & .92 & .72 & 7.32 \\
SI2 & .99 & .77 & 7.89 \\
SI3 & 1.00 & .69 & 7.05 \\
SI4 & & & \\
Supplier Responsiveness & 1.00 & .76 & - \\
SR1 & 1.11 & .89 & 9.52 \\
SR2 & 1.00 & .80 & 8.55 \\
SR3 & 1.13 & .86 & 9.22 \\
SR4 & & & \\
Buyer Performance Improvement & 1.00 & .95 & - \\
BPI1 & .94 & .89 & 14.66 \\
BPI2 & .81 & .83 & 12.78 \\
BPI3 & & & \\
\hline
\end{tabular}

36 
Table 2 - Correlation matrix and descriptive statistics

\begin{tabular}{|c|c|c|c|c|c|}
\hline Variable & 1. & 2. & 3. & 4. & 5. \\
\hline 1. Strategic purchasing & 1.00 & & & & \\
\hline Socialization mechanisms & 0.37 & 1.00 & & & \\
\hline Supplier integration & 0.41 & 0.39 & 1.00 & & \\
\hline 4. Supplier responsiveness & 0.09 & 0.09 & 0.33 & 1.00 & \\
\hline 5. Buyer performance improvement & 0.19 & 0.29 & 0.54 & 0.38 & 1.00 \\
\hline Mean & 3.43 & 3.85 & 4.50 & 4.84 & 4.40 \\
\hline Standard deviation & 1.67 & 1.46 & 1.22 & 1.16 & 1.19 \\
\hline Cronbach's alpha & 0.88 & 0.79 & 0.82 & 0.89 & 0.92 \\
\hline Composite reliability & 0.88 & 0.78 & 0.83 & 0.91 & 0.90 \\
\hline Average variance extracted & 0.72 & 0.54 & 0.55 & 0.79 & 0.64 \\
\hline
\end{tabular}

For $N=111, r$ has to be 0.189 or higher to be significant $(p<0.05)$ 


\section{Appendix A - Items and constructs}

\section{Strategic Purchasing $(\alpha=.88)$ established with suppliers

$\begin{array}{ll}\text { Socialization Mechanisms }(\boldsymbol{\alpha}=. \mathbf{7 6}) \\ \text { SOC1 } & \text { Cross-functional teams } \\ \text { SOC2 } & \text { Joint workshops } \\ \text { SOC3 } & \text { Co-location }\end{array}$

SP1 The purchasing function has a formally written long-range plan (e.g. a 5-10 year plan)

SP2 Purchasing's long-range plan is reviewed and adjusted to match changes in the company's strategic plans on a regular basis

SP3 Purchasing's long-range plan includes the various types of relationships to be

Supplier Integration $(\alpha=.82)$

SI1 The level of strategic partnership with suppliers

SI2 The participation level of suppliers in the design stage

SI3 The participation level of suppliers in the process of procurement and production

SI4 The establishment of a quick ordering system

\section{Supplier Responsiveness $(\alpha=.89)$}

SR1 Ability to modify product to meet our needs without excessive cost or time penalties

SR2 Responsiveness to our schedule delivery changes without excessive cost or time penalties

SR3 Ability to accept late 'mix' changes in orders

SR4 Responsiveness to our schedule volume changes without excessive cost penalties

Buyer Performance Improvement $(\alpha=.92)$

BPI1 In the last 2-3 years, we have continued to be able to improve product design performance through this supplier relationship

BPI2 In the last 2-3 years, we have continued to be able to improve process design through this supplier relationship

BPI3 In the last 2-3 years, we have continued to be able to improve product quality through this supplier relationship 